his compliance with the project to merge the German Democratic Republic (DDR) with the Federal German Republic (FRG). Gorbachev has a point: while arrangements for the security of Central Europe are in the air (and while his own position in the Soviet Union is unclear), the reunification of Germany is premature, to say the least.

Even so, the reunification of Germany is also inevitable. East Germans have for a year been able to move West if they chose. Up to 2,000 a week have been taking advantage of the opportunity. At that rate, the DDR would be emptied of people - except for the very old and, possibly, the very young - in about a decade. The result of that would be a social and military vacuum in Central Europe, especially in the eastern half. West Germany's Chancellor, Helmut Kohl, campaigned strongly during last December's East German elections, but he was merely acting prudently, seeking to avoid an intolerable dilemma.

Yet the pace of events is too fast for comfort. Those who have been engaged in relatively much simpler projects than the merger of whole countries - the merging of, say, departments of physical and inorganic chemistry - know that whole years may go by before a consensus is established. How can it be possible to merge two whole countries in a few months, which is the present intention? Only by taking a whole raft of considerations on trust, by agreeing in advance to agree on certain principles. The trouble with German reunification is that the only tangible agreement so far struck is that up to 6,000 marks of individual personal savings by East Germans will be converted into Deutschmarks at par, with the excess converted at the rate of two for one. It is also agreed that Ostmark salaries will be converted at face value into Deutschmarks, but that is a fiction: either the enterprises at which those concerned work are able to make their way in the competitive world, or they cannot. In the second case, the employees will have to look for work in West Germany, which is the reason why the German question arose in the first place.

The confusion is especially apparent in research. The West German grant-making agency called the Deutscheforschungsgemeinschaft has said that it will, from the beginning of next year, allow East German applications for funds to be considered alongside those from the West. But there is deep disagreement in West Germany about the criteria that should apply. Should the same standards apply to both, or should East German applicants be given an inside track? The first case would spell the end of research in East Germany, the second would breach the principle of excellence on which West German research has prospered in the past decade. Nobody knows how that will come out, nor what the Max-Planck Gesellschaft is up to. What it should be doing, of course, is to accept that the East German Academy of Sciences should be a titularly equal partner until things can be sorted out. In general, that is what the circumstances demand - time to sort things out.

\section{Labour's ambiguity}

THE British Labour Party, which hopes to be the next government, should have a policy on research.

THE British Labour Party, temporarily known as Her Majesty's Opposition (but which should constitutionally prefer to be known as Her Majesty's Government's opposition, where the capitalization of nouns is intended), last week produced its provisional agenda for the next British general election. The document is a frank disappointment. On higher education and research, there is only one tangible proposal - the funding councils that at present provide public money to universities and polytechnics will be merged (a sensible idea, on the cards since the late Mr Anthony Crosland invented British polytechnics in 1968). Otherwise, the document says nothing but that there is a need for skill and, therefore, for training as well as for equity in access thereto.

Even calculations of electoral advantage would have commanded a different tack. The present government, in office for 11 years, has ruined the capacity of British research to be imaginative by requiring it (in the proper public interest) to count pennies instead. British academics as different as aristotelians and theoretical physicists have become adept at the allocation of car parking spaces and, by all accounts, exceptionally skilled at telling when the government's apparently perpetual offer of early retirement on favourable terms will allow them to combine a half-time appointment at an American university with growing roses in a clement English county. Demographically, of course, it is even more troubling that younger scholars increasingly regard their first overseas postdoctoral appointment as their chance to play in a different league. The Labour Party's provisional manifesto says nothing on this point, and little to suggest that it would try to make Britain a more interesting place for researchers, in that role, to work. This is all a far cry from the then Mr Harold Wilson's "white-hot technological revolution". There were serious faults in that programme, but the cry was heartening, and electorally appealing.

Last week's document is similarly thin on research as such, which comes through as a handmaiden of industrial policy. The Labour Party (like the present government) would cut back on defence research. But the party's promise, at the last election, that research would be paid for by an industrial levy, is mercifully not repeated. It is nevertheless crucial to those working in research that there should be some undertaking of the scale and the direction in which research funds would be channelled. What the Labour Party should do, between now and the time that electoral considerations will require that it should publish a more substantial successor to last week's document, is to decide what science is for. The party evidently believes, on the evidence of last week's document, that research is either for wealth-creation (the present government's belief) or job-creation. Is that all? 